\title{
Long-Term Perspectives on River Floods. The Dominican Nunnery on Margaret Island (Budapest) and the Danube River
}

\author{
András Vadas ${ }^{\mathrm{a}^{*}}$ \\ ${ }^{a}$ Department of Medieval and Early Modern European History, Eötvös Loránd University, Múzeum krt. 6-8., 1088, Budapest, Hungary
}

\section{ARTICLE INFO}

\section{Article history:}

Received: 8. March 2013

Accepted: 9. May 2013

\section{Key words:}

Environmental history

environmental archaeology

flooding

historical hydrology

Danube

climate history

Little Ice Age

\begin{abstract}
$A B S T R A C T$
The study addresses the issue of the location of the Dominican nunnery on Margaret Island (formerly Insula Leporum, Budapest) from an environmental historical point of view. The building complex is situated extremely close to the Danube and has thus always been subject to flood danger. In this study, long-term trends in Danube flooding will be analysed to examine whether any shifts in flood magnitudes or in the hydrological conditions of the Danube are reflected in historical, archaeological and art historical data from the medieval building complex.
\end{abstract}

\section{Introduction}

Determining long-term trends in the fluctuation of waterlevels on a certain river is a complex task. Historical sources and archaeological data as well as data from the natural sciences can shed significant light on these issues. Fluctuation in the water-level of lakes in Hungary in historical times has been the focus of research for almost half a century (for an overview, see: Kiss 2009, 327-329). The long term shoreline changes at Lake Balaton (Western Hungary) has been the subject of scientific debate by historians, geographers as well as archaeologists since the 1960s (Sági 1968; Bendefy, Nagy 1969; Sági 1970; Bendefy 1972; Sági, Füzes 1973; Bendefy 1973 and more recently Sümegi et al. 2009a; Kern 2009). The second largest lake in Transdanubia (Western Hungary) area, Lake Fertő (Neusiedler See in Austria) has been studied extensively as well (Kiss 1998a; $1998 b ; 2001,71-77$, all with further literature on the topic). Geoarchaeological investigations in recent years have also contributed to an understanding of long-term changes

"Corresponding author. E-mail: vadinka86@gmail.com in the water-level of these lakes. There are also studies concerned with environmental changes in small lakes in the Transdanubian region and the Northern Mountain Range (Sümegi et al. 2009b; Zatykó et al. 2007; Zatykó 2008).

Research into long-term changes in the hydrological conditions of rivers in the Carpathian Basin still awaits, however, such comprehensive studies. In a ground-breaking dissertation, Andrea Kiss (Kiss 2011; also see based on this: Kiss 2012) discussed river flooding in mewdieval Hungary with reference to long-term trends in the fluctuation of lakes rather than the long-term changes in the water-levels of the rivers. Despite the tremendous efforts she carried out in order to collect references to flood events in medieval charters and narrative evidence she came to the conclusion that longterm trends in the hydrological changes of the major rivers can only be demonstrated with difficulty. Certain charters do contain evidence for changes in riverbeds connected to growing sedimentation (e.g. Fejér 1829-1844, XI. 224-225; Kiss 2011, 153-154,305) or changes in the hydromorphology of water courses (e.g. Kiss 2011, 151-153). Certain charters contain evidence implying changes in communication possibilities between settlements due to increases in flood 
frequencies (e.g. Hungarian National Archives. National Archives, Budapest. Collection of Diplomatics [henceforth: MNL OL DL] 63093. Published in: Fejér 1829-1844, VIII/1. 351, see also: Vadas 2011, 68-69).

Changes in the water regimes of rivers in Central Europe over the long period known as the Little Ice Age (henceforth: LIA; in Central Europe from the mid- $14^{\text {th }}$ to the $19^{\text {th }}$ century, see: Brázdil et al. 2005a, 388-394) has been an important focus of research in recent years (Pfister 1999; Brázdil et al. 1999; Brázdil et al. 2005b; Glaser et al. 2010). In this respect, major water courses in the region, particularly the Danube, are of primary importance as the changes in hydrological conditions may arguably be attributed to climatic changes and not merely to local regional scale environmental changes. Smaller water courses were drastically transformed through mining, milling, fisheries, etc. (Kiss 2011, 54-60; Ferenczi 2008) and consequently changes in flood conditions do not reflect what was occurring in more far-flung areas.

The aim of the present work is to trace the long-term changes in the flooding of the River Danube in the late medieval period. The analysis focuses on a narrow geographical area directly connected to the Danube, Margaret Island (Insula Leporum in the Middle Ages, in present day Budapest). In the Middle Ages, the Island was home to several ecclesiastical institutions including a Dominican nunnery, a Franciscan friary, a Premonstratensian monastery, the castle of the archbishop of Esztergom and the castle of the Hospitallers as well as a smaller peasant village. However, the exact location of this settlement is unknown (Éder et al. 2008; Irásné Melis 1991). The majority of the sources which mention Margaret Island refer to the Dominican nunnery which was one of the most significant ecclesiastical building complexes in medieval Hungary. Not only are the written sources preserved in relatively high numbers but there has also been intensive archaeological excavation at the building complex. Apart from excavation results and the extant written sources on the nunnery from the mid- $16^{\text {th }}$ century, pictorial evidence also contributes to the study of the changes of the close environment of the nunnery and its connections to the Danube River.

The building itself has been the subject of historical, archaeological and art historical research for over a century. Thanks to the relatively rich and surprisingly well-preserved cartulary of the nunnery and the sources on St. Margaret of Hungary, who lived most of her life in the Dominican nunnery, one finds numerous sources that refer in some form to the nunnery. Historiographic studies have focused a great deal on the question of the canonization of Margaret (most recently, see: Péterfi 2011, with further literature on the topic) and on the study of the book culture at the nunnery despite the fact that the documentation of the canonization trials of Margaret and the charters issued by or relating to the convent also contain significant information about the building itself and at times even the relationship between the building and the Danube.

\section{The water-levels of the Danube in the late medieval period - the state of research}

Despite the fact that no comprehensive study making use of contemporary evidence has dealt with the long-term hydrological regimes of the Danube thus far the problem has

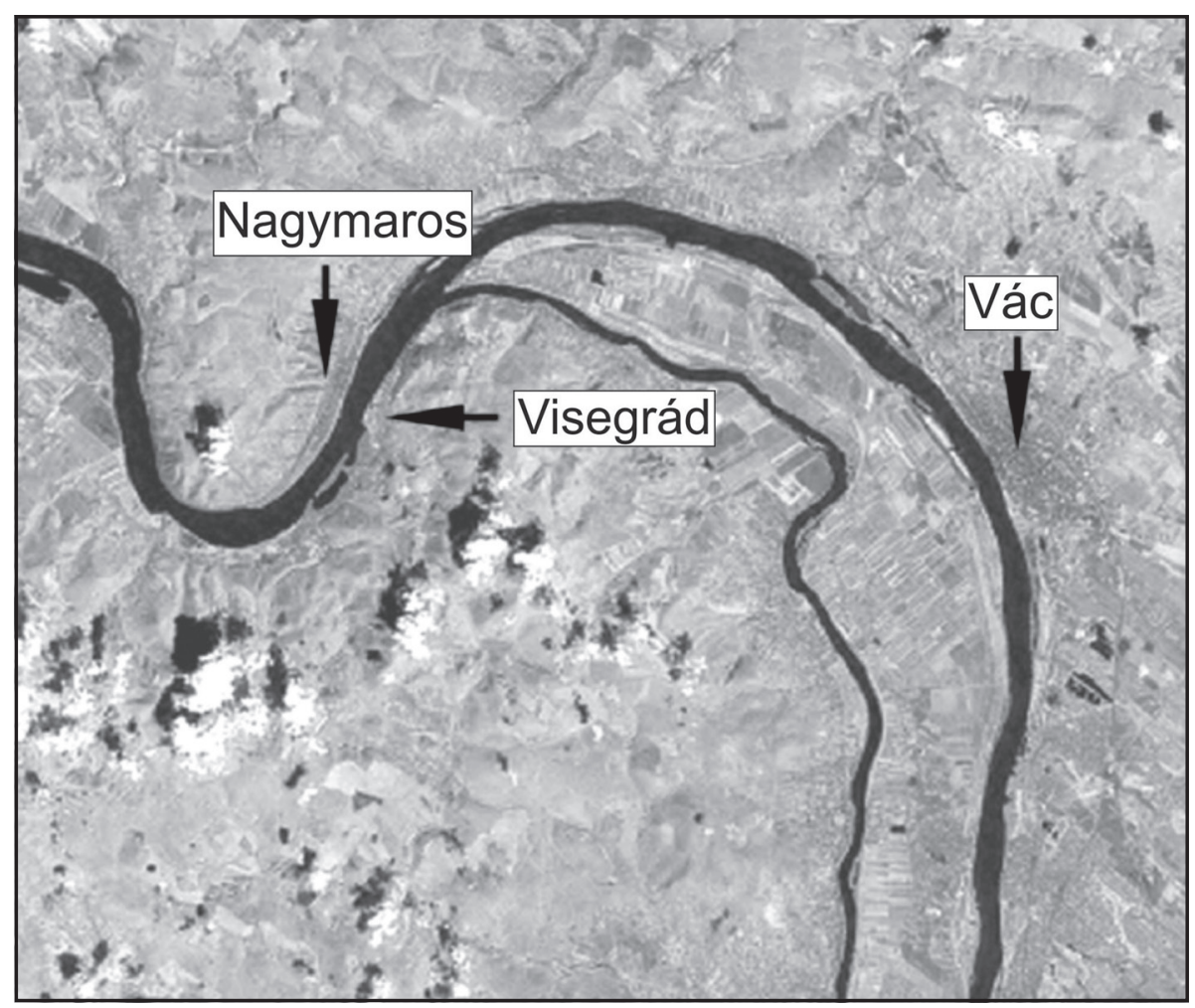

Figure 1. The Danube bend (after: Mészáros, Serlegi 2011). 
drawn the attention of several scholars (see Kiss 2011). The articles primarily noted that in a number of its sections within the Carpathian Basin, the Danube changed its bed significantly even in historical times (Pišút, Timár 2009; Székely et al. 2009) or drew attention in general to issues connected to the Danube and towns along its course (Szende 2010, 392-395). Although local environmental changes might have relevance when studying long-term trends in water regimes, it is also extremely important to demonstrate changes in run-off patterns, the hydrological regime or the maxima of water-levels. The changes in these parameters must have impacted the river along its entire course, this being something which could be of assistance in understanding whether the LIA had an impact on hydrological conditions in the Carpathian Basin in the late medieval period.

In recent years, it was archaeology that provided the most important results in the study of these issues. The majority of the data comes from a region not too distant from Budapest: the Danube Bend (or "Dunakanyar" in Hungarian, some 25 kilometres north of Budapest, see Figure 1). Individual case studies in the surroundings of the Danube Bend generally presume a significant rise in the average-water levels of the Danube in the late medieval period and thereupon elevated ground water-tables along the banks of the river (Páloczi Horváth 1979; Zsidi 2008; Mészáros 2006; Héjj 1988; Laszlovszky 2004; Jerem et al. in press; Mészáros, Serlegi 2011; Kiss, Laszlovsky in press). Soil science research connected to the planning of the never built dam (part of the GabčíkovoNagymaros Dams) at Nagymaros revealed there had been a catastrophic flood at a certain point at the end of the Middle Ages or in the first phase of the Early Modern Period (Páloczi Horváth 1979). Data from Visegrád, both from the royal palace (see: Kiss, Laszlovszky in press) and from the so-called New Town ("Újváros" in Hungarian) suggests that the shift in the hydrological regime of the Danube took place at some point around the end of the Middle Ages. Orsolya Mészáros (Mészáros, Serlegi 2011, 200-201, 207-214) studied sites on both the left (Vác) and the right (Visegrád) banks of the Danube River. She suggested that from the late medieval period, the Danube floods reached higher elevations than in previous times.

The archaeological cadastre of Hungary covers only about $10 \%$ of the country but has been carried out for the Danube Bend and the surroundings of Budapest for decades (Torma 1979; 1986; 1993). These volumes contained field surveys noting dozens of abandoned settlements along the banks of the Danube and with a clear tendency for medieval settlements to move towards higher elevations. This tendency is not only attested to along the Danube River but also by smaller lakes and streams in the area of the Great Hungarian Plain (Bálint 2006; Vadas 2011) and on the southern bank of Lake Balaton (Mészáros, Serlegi 2011).

\section{The Dominican nunnery and the Danube - sources and research possibilities}

As discussed above, the primary source for the work presented in this paper is the relatively rich cartulary of the nunnery of Margaret Island. The preserved charters relating to the Dominican community have been included in the edition of the cartulary of the bishopric of Veszprém (Franknói, Lukcsics 2007). Apart from the charters, research includes narrative sources on the life of Saint Margaret, most importantly the protocol of her first canonization trial based on the testimony of more than 100 witnesses of the miracles which occurred around Margaret herself. The protocol was gathered shortly after her death around 1276 and thus is true for her earliest Vita attributed to Marcellus, the confessor and the spiritual guide of the Árpádian princess. The investigation covered the later legend, the Legenda maior, as well. It was written in 1340 and contains a number of stories of the life of Margaret not included in the Marcellus legend (the Legenda vetus) or in the protocol and consequently must have used another oral or written account which has not survived. Apart from the written sources, research drew on an early image (a siege-map) which depicted the building complex since it also contributes significantly to the issue of the inter-connections between the Danube and the nunnery.

The other primary group of evidence integrated into the research includes the archaeological surveys on the building complex. For more than 150 years, archaeologists surveyed and excavated the nunnery complex. Over the first decades, however, it was more of a treasure hunt than surveying which took place in the area. Systematic excavation with reliable reports started in the 1960s. The excavations of Rózsa Feuerné Tóth (Feurné Tóth 1971) and Katalin Irásné Melis (Irásné Melis 2004; 2010; Irásné Melis, Tóth 2007) and most recently research by Eszter Kovács all contributed significantly to the study of the immediate environment of the nunnery and the relationship between the building complex and the Danube. The published results also touch on the question of the proximity of the Danube although the archaeological reports (particularly: Feuer 1961-1962; Irásné 2002; Irásné 2004) on these excavations provide little further data on the issue.

All together, these sources provide solid insight into the environment of the nunnery, particularly regarding Danube flooding during the lifetime of the nunnery and their impact on the building. In the following chapter, related sources will be discussed with special regard to the possibilities of demonstrating long-term transformations in the hydrological conditions of the Danube River.

\section{Results}

The Dominican nunnery on Margaret Island, due to its proximity to the Danube and the fact that the island itself is a low lying floodplain, has always been endangered by floods. It is highly unlikely, however, that one of its largest buildings would have been originally built on a site which was regularly inundated. Archaeologists discovered the remains of a village under the nunnery which suggests that this locale was inhabited from an early period. The primary reason for favouring this location is that the central part of 
the monastery was built on a small but observable elevation (a few dozen centimetres) which was removed during the construction of the royal court-house (Éder et al. 2008, 10) built over the site where the nunnery had been built.

The space provided is not sufficient to discuss the construction history of the building but it is crucial to emphasise that the protocol of the canonization trial of Margaret and the Legenda vetus both provide data on an early phase of the history of the nunnery (Harsányi 1938, 104-110; Feuerné Tóth 1971, 245-246). The protocol of Margaret contributes direct references to the issue of floods (the protocol is edited in Fraknói, Lukcsics 2007, 1. 159-383), as seven of the hundred persons who testified to the miracles performed by the princess, mentioned a miraculous flood (see Kiss 2011, 126-130). Despite the fact that Marcellus, a contemporary of Margaret and one of those who provided testimony in the protocol, experienced this event himself and gave an account of what he saw, he did not include this miracle in his Life of Margaret. It is even more surprising that according to the protocol he did not remember when the flood took place within the year; he thought it might have taken place at some time in April, when "floods usually occur" (Fraknói, Lukcsics 2007, 1.281). The miracle of the flood, however, was included in the Legenda maior written by Garinus (Gombos 1937-1943, III. 2468-2545 [for the chapter in question: Cap. 1:46-47. see: Gombos III. 2507-2508]), a French Dominican theologian who lived in the milieu surrounding the popes in Avignon (Deák 2005, 61-64).

The miracle, despite the fact that Andrea Kiss (Kiss 2011) analysed the protocol with great care regarding the flood report, contains certain elements still worth discussing. Seven of the witnesses in the protocol mention a flood (or rather floods) on the Danube which in all probability took place in the winter of $1267 / 68$. As the testimony of these witnesses is analysed the aim is to draw attention, on the one hand to the issue of the validity of the flood event based on their descriptions, and on the other to catalogue the parts of the building (for the ground plan of the nunnery see Figure 2) affected by the described event. The latter may provide important information on the magnitude of the event and how the proximity of the Danube impacted the building.

Dame Margaret (Domina Margaretha), the first witness who mentions the flood, testifies that the river inundated the court (cortem) where the nuns lived. As the nuns spent the majority of their time in the enclosed part of the building, the court in this case is likely to have referred to the cloisters, the central part of the building. The other element in the testimony, which occurs in the majority of the accounts of other witnesses as well, is the disbelief of Marcellus. According to Dame Margaret and other witnesses, when Marcellus, confessor to the nuns, arrived at the nunnery, St. Margaret reported that the flood had passed through in the preceding days. She even described the water reaching the cloisters. The second flood came when Marcellus expressed his doubts about this account. According to the testimonies, Margaret then prayed to the Virgin Mary to show the Dominican friar that Margaret was telling the truth. This second flood wave was again serious and reached the floor of the nunnery as Marcellus had to climb up on some kind of tree branch so as not to be swept away. One element needs to be emphasised here, this being the fact that for the friar, such high water-levels on the Danube were difficult to imagine. Marcellus had been in the Dominican order for decades by this time and might have been living on Margaret Island for an extended period of time by the $1260 \mathrm{~s}$. This suggests that he was well aware of the possible strongest inundation. Hence his doubt (particularly taking into account the characteristics of hagiography as a genre) since floods normally did not reach the floor of the building. The further six accounts of the protocol on the miracle of the flood all relate of the same episode in general terms, thus, the analysis only goes into detail at the points where the different witnesses mention different circumstances.

Dame Elisabeth's (Domina Elisabeth) account is almost the same as that given by Margaret. The third witness (also called Margaret) mentions, however, that the Danube waters entered the servants' courtyard in the nunnery (curtem servitialium). The account here differs significantly. According to Margaret, Marcellus was surprised, not by the fact that the water entered the building, but by the fact that it reached as far as the servant's courtyard. The next witness, a certain Dame Benedicta (Domina Benedicta), also mentioned the place where the servants were housed.

The fifth account, the one by Dame Olimpiades (Domina Olimpiades the magistra of the nunnery at that time) is more detailed than the preceding ones. She mentions as well that during the two flood events both the natural one and the flood which occurred when Marcellus was present, reached the courtyard of the servants. During the second flood even the cloisters (claustrum monialium) were inundated. Olimpiades also testified that during the second wave the nuns remained outside the closed area of the nunnery in the kitchen garden. When they saw the flood coming the nuns ran into the cloisters to the chapter house, supposedly because they were aware that it was more protected from floods than other parts of the building complex. However, this elevation proved insufficient to protect the nuns who consequently had to climb onto a branch of a tree.

The penultimate testimony which mentions the floods was provided by Dame Alexandria (Domina Alexandria) and significantly differs from the ones discussed above. The nun gave an account of a series of events which did not occur in any other testimony. Alexandria mentions a flood event which is extremely likely to have been an individual flood event having nothing to do with the inundation which occurred in two waves and which was mentioned by all the other nuns. According to Alexandria, once the Danube swelled so high that the nuns thought the water would inundate the kitchen. At that time, the kitchen was close to the cloisters in the eastern part of the building complex, on the Danube side of the nunnery. Despite the danger, Margaret remained awake all night and was preparing all the items in the kitchen needed to cure the sick people who were treated at the nunnery. According to Alexandria, the presence of Margaret protected the building from the flood. 
Figure 2. The ground plan of the Dominican nunnery on Margaret Island (after FeuernéTóth 1971 and Irásné Melis 2007).

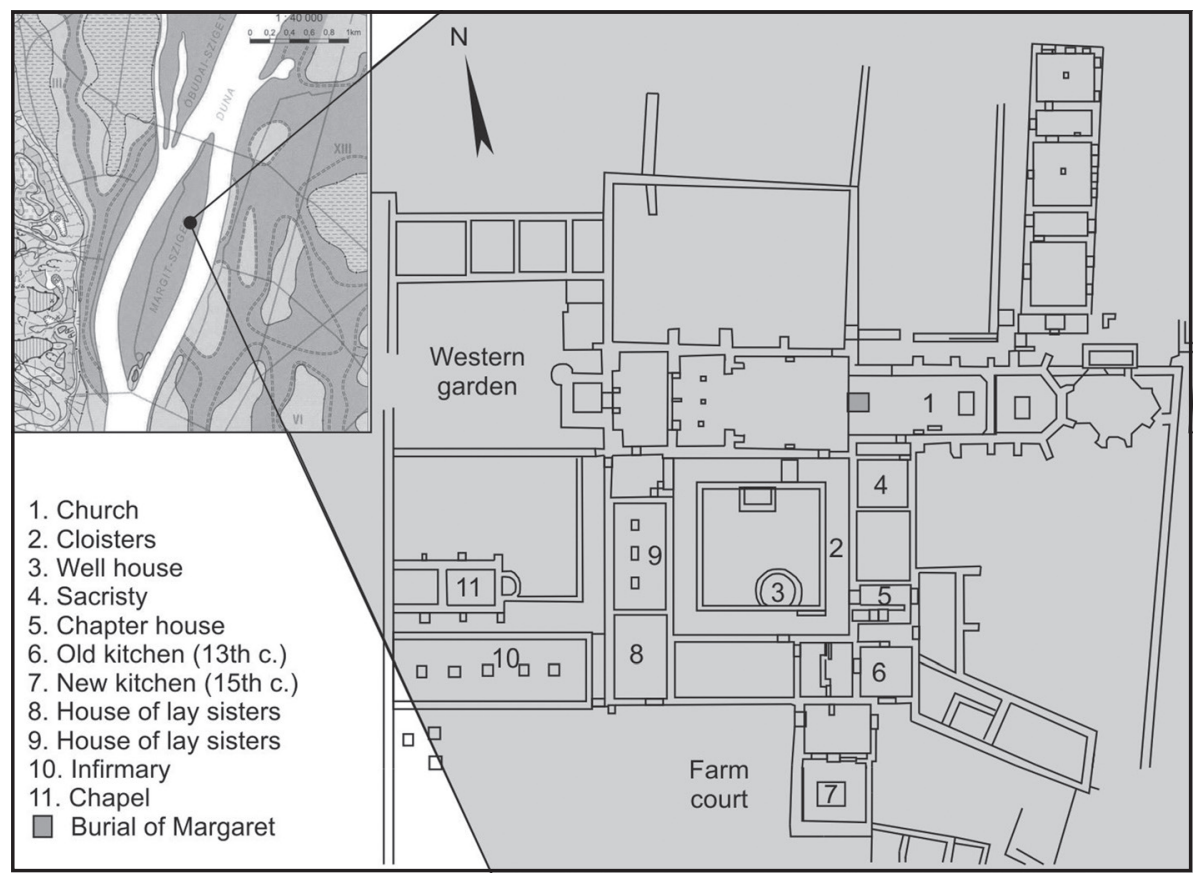

After her description of this event, Alexandria relates of the double inundation mentioned by all five people who provided testimony. Alexandria mentions that the first flood wave indeed reached the servant's courtyard as well as the infirmary building. The location of the latter was identified during the excavations by Feuerné (Feuerné Tóth 1971, 265-266) in the western part of the building complex along with the servants' courtyard, both of which lie further away from the Danube. This, the second wave, not only flooded the cloisters but reached as far as the fences of the complex which suggests that the entire nunnery was under water during this flood event.

The last to testify, Marcellus provides the most detailed information regarding the floods. He, as noted above, did not witness the first wave of the flood and only testifies on the second event, the fast rising of the water-level when he could scarcely believe his own eyes. He testifies that the water rapidly increased. He relates of the nuns and himself being covered to a certain height. Marcellus reports that they had to flee in order to be rescued from the flood waters. He, and supposedly the others who were present, climbed on top of the columns of the cloister (perhaps meaning the balustrade of the cloister) in order to reach the already mentioned branch or wooden structure.

The testimony in the protocol of all the witnesses provides important information to estimate the extent of the flood although it always has to be taken into account that hagiography as a source for flood magnitudes is loaded with a number of uncertainties. The sources provide relatively abundant data on the rooms of the building complex which were impacted by the floods. Based on archaeological excavations, the function of the various parts of the nunnery could be identified with relative assurance and the excavation reports provide exact data on the elevation of the floor of the rooms. The floor of the cloisters and the infirmary sit at 102.7 meters above the Adriatic Sea level as are the majority of the rooms in the building. The courtyard of the servants appeared in most of the testimonies. This area can be identified either with the Farm court or the Western court. This may be of significance as their floor level was some 20 centimetres higher than those of the infirmary or the cloisters. The top of the columns in the cloister must have been at least two metres higher although there was likely to have been a certain amount of exaggeration in order to prove the miracle was valid. This is why it is also possible that the testifiers here actually meant the balustrade of the cloister, being less than a metre higher than the floor of the building. Drawing conclusions on the exact water-level using this data would not be valid because if the report of witnesses was truly accurate, the entire ground floor of the monastery would have been flooded, as well as the whole of Margaret Island. Such high water-level would occur only in case of serious ice-floods when an ice barrier is built up by the water which holds it back until the ice begins to break up during a thaw (Kiss 2011). Similar instances are known from the $18^{\text {th }}$ century with the most catastrophic flood in Pest-Buda ever (Kiss 2007), the one which took place in 1838, being a consequence of an ice barrier in the southern part of presentday Budapest (at the Kopaszi Dam) which held the water back.

Information on the floods which reached the nunnery is provided by additional sources apart from the protocol. Before turning to an important charter which touches on the issue of the floods, certain elements of the rich hagiographic literature on the life of Margaret should also be discussed.

As mentioned above, the earliest legend concerning Margaret did not refer to the "flood-miracle" although the legend written by Garinus included the legend. Not only did 
Garinus include mention of the flood connected with the arrival of Marcellus, but he also included the flood event described by Dame Alexandria (for the text of the legend see Gombos 1937-1943, III. 2508, 1:47). This as well as the double inundation of the Danube River was described by Garinus along with the Biblical Exodus, the flooding and the division of the Red Sea. According to the Legenda, when the water inundated the nunnery for the second time, Margaret herself was frightened by the forces she had brought into action through her prayer. The nuns, afraid their building would collapse, went to see Margaret asking her to pray to God to save their community from danger. The waters consequently retreated rapidly and within a few hours the whole of the nunnery had dried and no harm was caused to the building. The description of this miracle by Garinus clearly includes the protocol but also differs significantly as it describes the fear of Margaret and her prayer to stop the floods.

The appearance of similar miracles in hagiographical works is not unheard of but certainly rare and even more interesting is the fact that the protocol mentions another parallel case, when Margaret prays for a heavy rain. Yet another case is known from the Garinus legend, which relates of another miraculous episode when the Princess quiets a strong wind. Michael Goodich refers to certain late medieval parallels although it is quite unusual that God is depicted arousing and not calming a particular certain natural force based on the will of a blessed person (Goodich 1995, 103-210).

One other piece of hagiographic-type literature is worth discussing here, the so-called Hungarian Legend. This is a rather unusual piece of hagiography, being on the one hand one of the earliest Hungarian vita for any saint of the Middle Ages, and on the other hand merely a simple translation. It includes the Legenda vetus of Marcellus and certain later versions of the protocol (Dömötör et al. 1990). In the Hungarian Legend, despite the fact that it commemorates the life of the Princess, the author frequently refers to circumstances in the $16^{\text {th }}$ century as well. One of these notes sheds light on the connections between the nunnery and the Danube. When describing the obedience of Margaret, the work notes that she frequently cleaned the latrines, which at the time (meaning Ráskai's own time), "was called the Danube". The latrines of the nunnery have not yet been found. Based on European parallels, however, and the slope of the surveyed channels the latrines may have been situated close to the Danube in the south-east part of the complex (Feurné Tóth 1971, 261). The fact that in the late medieval period the latrines were referred to as the Danube may indicate that the place was frequently flooded or that the underground watertable was higher than previously.

Despite the fact that there is a relative abundance of charters relating to life at the monastery from the late medieval period, most are not connected directly with Margaret Island itself, but rather concern the more distant estate issues of the nunnery. There is, however, an extremely important charter from the early $16^{\text {th }}$ century. Thommaso de Vio, a papal legate and cardinal (Kalous 2010, 377-379), issued a charter on 5 September 1523. In it he grants permission to the nunnery of Margaret Island to move the remains of "Blessed Margaret". Lea Ráskai mentions in one of her works that in 1510 reconstructions were begun in the sanctuary of the church. During this work, amongst other restoration steps, the floor of the sanctuary was raised (Bognár, Levárdy 1960, 196 [46] [28]). Ráskai also adds that it was the vaulting where the restoration work first took place. The nun mentions in the Hungarian Legend that Margaret's burial was still intact in the early $16^{\text {th }}$ century, thereby indicating clearly that the Princess was still buried in the nunnery church when the work was launched. There is, however, an art history source which leaves no doubt that at some point between 1510 and 1512, the grave was opened. Lajos Némethy discovered an inventory of the belongings of the Poor Clares in Bratislava (Pressburg) from 1782 which lists a reliquary (cistula) made in 1512 in which Margaret's bust was usually shown (1 cistula argentea deaurata, opus anni 1512. cui inponitur pro publico cultu Caput Stae [sic!] Margarethae, see: Némethy 1884, 31-32 and 240-241). The unsealing of the grave was a precondition for the construction of the reliquary, therefore at a certain point in the early $1510 \mathrm{~s}$ Margaret's grave was opened and her relics removed from their original location, the grave site by the entrance to the sanctuary of the church. The remains of the Princess were consequently placed at some point outside the church within the closed area of the nunnery (Némethy 1884, 26-34; Király 1979, 143-144). The nunnery, however, was not open to pilgrims after the early 1510 s and the remains of Margaret were no longer on public display. The primary reason for the nuns to show Tommaso de Vio the place where the bones of Margaret (ossa beate Margarete virginis) were kept was to procure permission from the cardinal to place the relics in a location where they could be visited. One of the possible places was the church, of course, which by that time had been restored. In the early $16^{\text {th }}$ century, however, Margaret had not yet been canonized (she was finally canonized only in 1943). Thus, it was not apparent that her bones should be put on display for veneration. The church would have been an obvious choice as it was open to pilgrimage for the majority of the year. Béla Iványi discovered a note of permission issued in 1499 which granted ten days each year for the nuns to visit the remains of Margaret in the church. This circumstance indicates that in the remaining part of the year the burial of Margaret (and that of King Stephen V) was open to the wider public (Harsányi 1938, 105).

According to the charter issued by Cardinal Thommaso, he visited the place where Margaret's relics were kept in 1523 (Nos [...] qui vobis videbuntur ossa huiusmodi in ecclesiam monasterii vestri). As noted, the fact of the relocation of the bones was acknowledged by several scholars although none of them discussed the charter's reasoning behind this act which is of primary importance regarding the longterm flood history of the Danube. The nuns justify asking for permission to move Margaret's bones because the place where the remains of Margaret were buried was subject to Danube floods (Cum nuper apud monasterium vestrum 
diverteremur, ostensa nobis per vos fuerunt ossa beate Margarete virginis monialis vestre filie quonadam clare memorie Bele quarti regis hungarię in loco ut asserebatis exposito aquarum inundationibus. Et quoniam illam vite sanctimonia non minus quam prosapia claruisse asserebatis nobis humiliter supplicastis ut illa inde transferri et in loco decentiori in quo inundationes huiusmodi non officerent poni permitteremus - MNL OL DL 25312, for the most recent edition of the charter see: Kalous 2010, 379). Thus, it was not one disastrous flood which reached the nunnery but, according to the nuns, the nunnery was exposed to flood danger on a regular basis: ut asserebatis exposito aquarum inundationibus. Unfortunately, there is no data on the location of the relics at that time although it is highly unlikely that the nuns in the early 1510 s placed their most precious objects in a place where it was exposed to destruction. The nuns could have made mention of the flood danger in order to convince the Cardinal of the necessity of bringing Margaret's relics back to the church and place her remains out for veneration despite the fact that her canonization had still not taken place at that point. Nevertheless, it is extremely probable that the reasoning was not entirely fallacious and that parts of the enclosed area of the nunnery were flooded in the early $16^{\text {th }}$ century from time to time.

Despite the dubiousness of the validity of the permanent flood danger to the monastery in the 1520 s, information on late medieval flooding of the Danube is worthy of discussion (Kiss 2011, 139-145, 252-258) at other sections of the river. In the Hungarian sources, there are only a few confirmed cases from the Jagiellonian period (1490-1526). The memory of these events may have been preserved by the nuns living in the community. As concerns foreign sources, there is mention of a serious Danube flood in 1501 which must have reached Hungary and the memory of which may have been preserved amongst the nuns. The flood had devastating impacts in Austria (Rohr 2005, 72-76; 2007, 235-243) and based on its magnitude the wave must have reached the Carpathian Basin as well. There is no evidence of the destruction caused by this flood at the nunnery but it could have easily happened that the nuns were aware of this past flood event.

In Austria, there is knowledge of a significant flood from 1508 as well which according to Antal Réthly may have also reached Hungary (Réthly 1962, 59-60). Despite doubts surrounding the authenticity of Réthly's sources, it is likely that the flood in the summer of 1508 did indeed reach the Carpathian Basin. There is a rather unique source, an account book of the journey of two canons from the Bratislava chapter who had to travel to Buda through Esztergom. On their return journey, at a certain point after 27 July 1508, the canons noted that one of the branches of the Danube (the Malý Dunaj, in Slovakia) was flooded which made it difficult to continue on their way back to the chapter house (Item de Gwtha usque Wasaruth vectori, in maxima aqua nos ducenti solimus, see: Anonymous 1863, 224). One finds no direct information concerning the destruction incurred during these floods on the island although in these years the remains of
Margaret were buried deeply under the ground floor of the nunnery, below the sanctuary of the church, in a place more flood endangered than any other part of the building complex itself. The nuns could have also preserved the memory of the issue of relics being endangered by this annual or bi-annual phenomenon.

The rise in ground-water or increase in the magnitude of floods in the late medieval period can be confirmed by archaeological data as well. During excavations over the last few decades, archaeologists discovered a 40 to 60 -centimetre banking up in the floor of several parts of the nunnery (Irásné Melis, Tóth 2007, 109). These earthworks date back to the end of the Middle Ages, the period when the abovementioned Ráskai herself, who reported the restoration work, lived in the nunnery. These earthworks were not characteristic in all sections of the building complex. In a number of the excavation trenches, such as those in the western courtyard, the north-west corner of the cloisters and the trench next to the house of the lay sisters there was no sign of such earthwork activity. These building sections were, however, generally more elevated (102.9 meters above Adriatic Sea level) than the parts which needed to be raised (Kovács 2011). There were two reasons for this. On the one hand, it was possible that there was no need to raise these building sections as they were not affected by the river floods and on the other hand it is also possible that the work had not been completed by the time the nunnery was finally abandoned in 1529 due to the Ottoman threat. It also has to be taken into account that the first major excavations in the 1930s never documented possible areas of embankment work. In places where the ground levels were raised, as in the infirmary and the apse of the church, the new elevated floor sat at around 103.3 meters above the Adriatic Sea level (Feuer 1961-62, 8; Irásné Melis 2002, map: 18.982; Irásné Melis 2004). Not only was the ground level of the apse of the church raised but the exterior of the sanctuary was also significantly banked up in the early $16^{\text {th }}$ century.

According to Irásné and Tóth, the issue of floods at the nunnery is also depicted in an early representation of the siege of Buda from 1542 (Irasné Melis, Tóth 2007, for the siege map: National Széchényi Library Budapest. Department of Old Prints. Apponyi Collection [henceforth: OSzK RNyT App.] MS 25; see also: Végh 2004). They noticed that Enea Vico's engraving depicts the nunnery with poles surrounded by boughs on the Danube side of the building which might have been intended to serve as a defence against ice floods. Although there are debates concerning the accuracy of Vico's engraving, the details of the Dominican nunnery suggest that at least this part of the image is relatively precise. Irásné and Tóth (2007) suggest that the accuracy of the poles on the image was confirmed by excavation results from the 1990s. During work on the eastern side of the building, exploratory excavation revealed post holes. There is a somewhat unclear point regarding these protective fences, however. Vico's image represents the state of the building in the early 1540 s by which time the nunnery had been abandoned for more than a decade with the survival of these wooden 


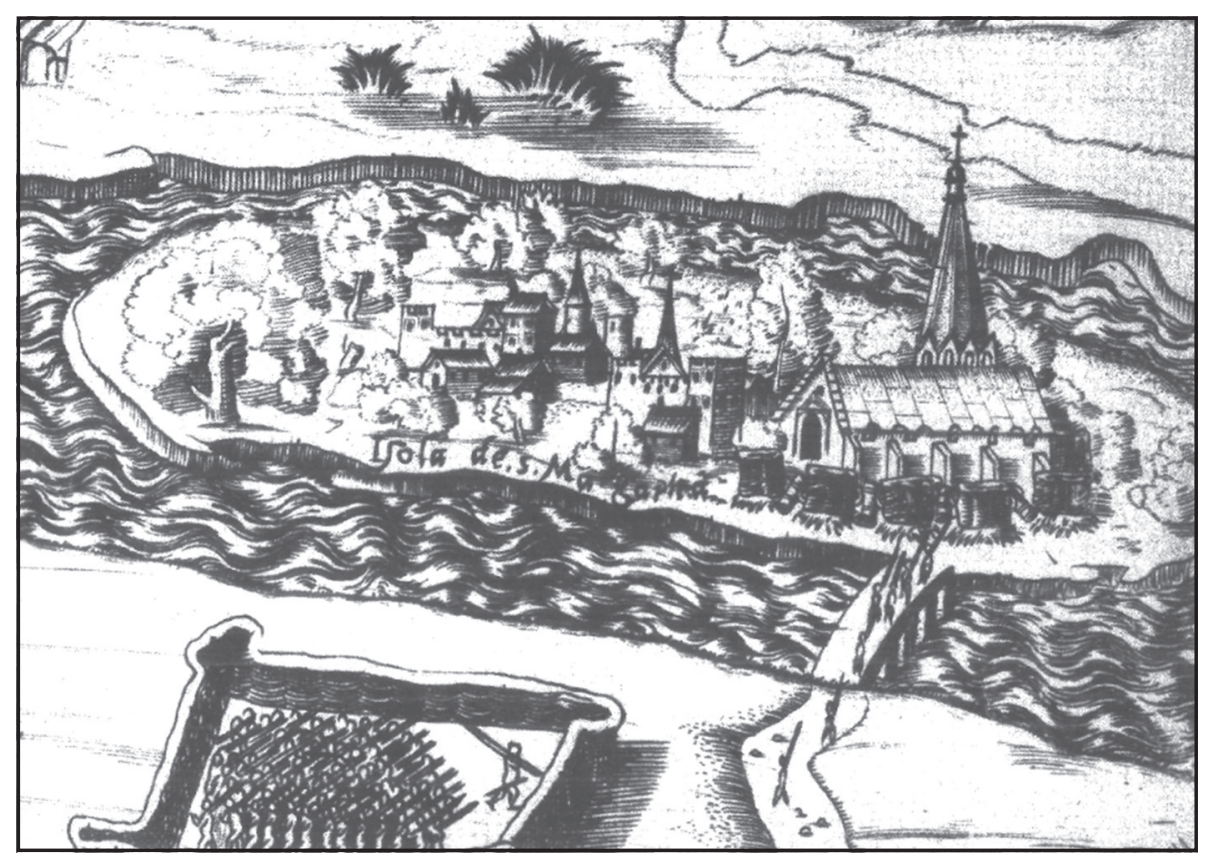

Figure 3. Margaret Island on the siege map of Enea Vico from 1542 (OSzK RNyT App. MS 25)

structures for such a long time being rather unlikely. Even considering this problem, it is possible that the ice caused increasing problems during winter floods in the late history of the nunnery and the nuns consequently built a permanent protective bough-fence.

\section{Conclusion}

The aim of the study was to explore the riverine environment of the late medieval Dominican nunnery on Margaret Island during this part of the LIA. The sources which may contribute to an understanding of the flooding of the Danube and its impact on the Dominican nunnery are varied. They are difficult to integrate with one other and include historical, art historical and archaeological data. The archaeological results both at different sites upstream (the Danube Bend) along the Danube indicate that in the late medieval period the river began to cause more problems than it had before: cellars had to be filled (Laszlovszky 2004; Kiss, Laszlovszky in press), wells became unusable (Mészáros, Serlegi 2011). On Margaret Island as well, in the early $16^{\text {th }}$ century, both historical and archaeological data suggest that floods or a rising water-table endangered the nunnery more often than it had before. This does not mean, of course, that water had not been a permanent problem during the centuries of life at the nunnery complex. It is probable, however, that something changed regarding hydrological conditions on the Danube by Margaret Island. Nevertheless, it would be premature to connect these changes to climatic-environmental reasons caused by the LIA or to supposed major environmental changes over a wider region based on the charter from 1523 and the physical earthworks designed to raise the floor of the different building sections. Additional case studies will be necessary in order to be able to make general conclusions regarding connections between these various processes.

\section{Acknowledgements}

The author would like to express his special thanks to Eszter Kovács (Budapest Historical Museum), Gábor Klaniczay (Central European University), József Laszlovszky (Central European University) and Bence Péterfi (Eötvös Loránd University) for sharing their data and wisdom. The help of Alice M. Choyke was indispensable in the completion of the article due to her suggestions and for improving the English. The work could have never been carried out without data from the archives of the Budapest Historical Museum. The excavation reports of Katalin Irásné Melis and Eszter Kovács were both provided by the institution.

\section{References}

ANONYMOUS [KNAUZ, N.] 1863: A középkori olcsóság, Magyar Sion $1,221-228$

BÁLINT, M. 2006: Az Árpád-kori településhálózat rekonstrukciója a Dorozsma-Majsai Homokhát területén. MS. PhD thesis. Deposited: Library of the Eövtös Loránd University, Budapest.

BENDEFY, L. 1972: Természeti és antropogén tényezők hatása a Balaton vízállására, Földrajzi Értesitö 22/3, 335-358.

BENDEFY, L. 1973: A Máriaasszony-szigeti templom és a Balaton középkori vízállása, Földrajzi Értesitö 22/1, 143-151.

BENDEFY, L., V. NAGY, I. 1969: A Balatonévszázados partvonalváltozásai. Müszaki, Budapest.

BOGNÁR, A., LEVÁRDY, F. 1960: Példák könyve 1510. Hasonmás és kritikai szövegkiadás. Akadémiai Kiadó, Budapest.

BRÁZDIL, R., PFISTER, Ch., WANNER, H., von STORCH, H., LUTERBACHER, J. 2005a: Historical Climatology in Europe - The State of the Art, Climatic Change 70, 363-430.

BRÁZDIL, R., DOBROVOLNÝ, P., EllEDER, L., KAKOS, V., 
KOTYZA, O., KVĚTOŇ, V., MACKOVÁ, J., MÜLLER, M., ŠTEKL, J., TOLASZ, R., VALÁŠEK, H. 2005b: Historické a současné povodně $v$ České republice. Masarykova univerzita, Český hydrometeorologický ústav, Brno-Praha.

BRÁZDIL, R., GLASER, R., PFISTER, C., DOBROVOLNÝ, P., ANTOINE, J.-M., BARRIENDOS, M., CAMUFFO, D., DEUTSCH, M., ENZI, S., GUIDOBONI, E., KOTYZA, O., RODRIGO, F. S. 1999 Flood events of selected European rivers in the Sixteenth century, Climatic Change 43, 239-285.

DEÁK, V. H. 2005: Árpád-házi Szent Margit és a domonkos hagiográfia. Garinus legendája nyomán. Kairosz, Budapest.

DÖMÖTÖR, A., PÓLYA, K., P. BALÁZS, J. 1990: Szent Margit élete, 1510: A nyelvemlék hasonmása és betühü átirata bevezetéssel és jegyzetekkel. Magyar Nyelvtudományi Társaság, Budapest.

ÉDER, K., KOVÁCS, E., VIEMANN, Z. 2008: Budapest, XIII. kerület Margitsziget. Régészeti hatástanulmány. MS. Deposited: Library of the Budapest Historical Museum, Budapest.

FEJÉR, G. 1829-1844: Codex diplomaticus Hungariae ecclesiasticus ac civiles. I-XI. Typis Typogr. Regiae Vniversitatis Vngariae, Budae [Budapest].

FERENCZI, L. 2008: Vízgazdálkodás a középkori Magyarországon. In: Kubinyi, A., Laszlovszky, J., Szabó, P. (Eds.): Gazdaság és gazdálkodás a középkori Magyarországon. Martin Opitz, Budapest, 341-362.

FEUER, I. 1961-1962: Domonkos kolostor ásatásának dokumentációja MS. Excavation report: nr. 519-77. Deposited: Library of the Budapest Historical Museum, Budapest.

FEUERNÉ TÓTH, R. 1971: A margitszigeti domonkos kolostor, Budapest Régiségei 22, (1971) 245-269.

FRAKNÓI, V., LUKCSICS, J. 2007: A veszprémi püspökség római oklevéltára/Monumenta Romana episcopatus Vesprimiensis. [CD-ROM] Veszprémi Érseki és Főkáptalani Levéltár, Budapest.

GLASER, R., RIEMANN, D., SCHÖNBEIN, J., BARRIENDOS, M., BRÁZDIL, R., BERTOLIN, C., CAMUFFO, D., DEUTSCH, M., DOBROVOLNÝ, P., VAN ENGELEN, A. 2010: The variability of European floods since AD 1500, Climatic Change 101, 235-256.

GOMBOS, F. A. 1937-1943, Catalogus fontium historiae Hungaricae aevo ducum et regum ex stirpe Arpad descendentium ab anno Christi DCCC usque ad annum MCCCI. I-IV. Szent István Akadémia, Budapest.

GOODICH, M. E. 1995: Violence and Miracle in the Fourteenth Century. Private Grief and Public Salvation. University of Chicago Press, Chicago.

HARSÁNYI, A. 1938: A domonkos rend Magyarországon a reformáció elött. Pázmány Péter- Tudományegyetem történelmi szemináriuma, Debrecen.

HÉJJ, M. 1988: Településföldrajzi megfigyelések. Visegrád a 14-16. században. In: Köblös, J. (Ed.): Visegrád 1335. Tudományos tanácskozás a visegrádi királytalálkozó 650. évfordulóján. Pest Megyei Levéltár, Budapest, 47-62.

IRÁSNÉ MELIS, K. 1991: Die Margareteninsel und ihre Klöster im Mittelalter. In: Biegel, J. (Ed.): Budapest im Mittelalter. Braunschweiges Landesmuseum - Budapest Historical Museum, Braunschweig, 409-414

IRÁSNÉ MELIS, K. 2002: Budapest XIII. Domonkos apácakolostor Régészeti kutatás 1999. MS. Excavation report: nr. 2023-2002. Deposited: Library of the Budapest Historical Museum, Budapest.

ÍRÁSNÉ MELIS, K. 2004: A Budapest Margit-szigeti domonkos apácakolostor pusztulása a 16-17. században. Budapest Régiségei 38, $107-120$

IRÁSNÉ MELIS, K. 2004: Budapest XIII. Domonkos apácakolostor. Templom, poligonális záródású szentélytoldás - 16. századi régészet adatok. 2002. november 20. MS. Excavation report: nr. 2081-2004. Deposited: Library of the Budapest Historical Museum, Budapest.

IRÁSNÉ MELIS, K. 2010: A budapest-Margit-szigeti középkori királyi udvarhely es a domonkos apácakolostor kutatása. Régészeti, történeti adatok In: Benkö, E., Kovács, Gy. (Eds.): A középkor és a kora újkor régészete Magyarországon I-II. MTA Régészeti Intézet, Budapest, I. 421-438.

ÍRÁSNÉ MELIS, K., TÓTH, A. 2007: A Budapest Margit-szigeti királyi udvarhely és a domonkos apácakolostor területén előkerült építészeti kőtöredékek katalógusa, Budapest Régiségei 40, 179-219.

JEREM, E., LASZLOVSZKY, J. SZABÓ, P., VÁSÁROS, Z., VÉGVÁRI, Z. in press: A Historical Landscape at the Crossroads of Cultures: A Digital Landscape at the Crossroads of Computer-Aided Reconstructions and GIS Approaches. MS.
KALOUS, A. 2010: Plenitudo potestatis in partibus? Papežšti legáti a nunciové ve středni Evropě na konci středověku (1450-1526). Matice moravská, Brno.

KERN, Z. 2009: Balaton-felvidéki tölgyek évgyürüszélességének kapcsolata a Balaton vízszintingadozásával. In: Kázmér, M. (Ed.): Környezettörténet. Az elmúlt 500 év környezeti eseményei történeti és természettudományi források tükrében. Hantken Kiadó, Budapest, 357366.

KIRÁLY, I. 1979: Árpádházi Szent Margit és a sziget. Szent István Társulat, Budapest.

KISS, A. 1998a: Changing environmental conditions and the waterlevel of Lake Ferto (Neusiedlersee) before the drainage works $\left(13^{\text {th }}-18^{\text {th }}\right.$ centuries), Annual of Medieval Studies at CEU 1997-1998, 241-248.

KISS, A. 1998b: Historical study of the Changing Landscape of Lake Fertö/ Neusiedl during the Late Middle Ages $\left(12^{\text {th }}-15^{\text {th }}\right.$ centuries $)$. MS. Master diploma thesis. Deposited: Library of the Central European University, Budapest.

KISS, A. 2001: Hydrology and environment in the southern basin of Lake Fertö/Neusiedl in the late Middle Ages, Medium Aevum Quotidianum 44, 61-77.

KISS, A. 2007: „Suburbia autem maxima in parte videntur esse deleta” Danube icefloods and the pitfalls of urban planning: Pest and its suburbs in 1768-1799. In: Kovács, C. (Ed.): From Villages to Cyberspace. University Press, Szeged, 271-282.

KISS, A. 2009: Historical Climatology in Hungary: Role of Documentary Evidence in the Study of Past Climates and Hydrometeorological Extremes, Idöjárás 113/4, 315-339.

KISS, A. 2011: Floods and Long-Term Water-Level Changes in Late Medieval Hungary. MS. PhD thesis. Deposited: Library of the Central European University, Budapest.

KISS A. 2012: Dunai árvizek Magyarországon a középkori írott források tükrében: 1000-1500. Esettanulmányok, forráskritika és elemzési problémák. In: Kiss, P. A., Piti F., Szabados Gy. (Eds.): Középkortörténeti tanulmányok 7. Középkorász Műhely, Szeged, 339-355.

KISS, A., LASZLOVSZKY, $J$ in press: $\left(14^{\text {th }}-\right) 16^{\text {th }}$-Century Danube Floods and Long-Term Water-Level Changes in Archaeological and Sedimentary Evidence in the West and Central Carpathian Basin. Journal of Enviromental Geography.

KOVÁCS, E. 2011: A margitszigeti domonkos apáca kolostor ásatásai. MS. Excavation report. (not yet deposited at the Library of the Budapest Historical Museum)

LASZLOVSZKY, J. 2004: Királyi palota, ferences kolostor és városi település (Gondolatok a késő középkori Visegrád településfejlődéséről). In: F. Romhányi, B., Grynaeus, A., Magyar, K., Végh, A. (Eds.): Es tu scolaris. Ünnepi tanulmányok Kubinyi András 75. születésnapjára. Budapesti Történeti Múzeum, Budapest, 61-71.

MÉSZÁROS, O. 2006: Késő középkori ház Visegrád polgárvárosában Fő utca 32. (Birkl-telek). Héjj Miklós és Parádi Nándor ásatása, 1963, Archaeologiai Értesitö 131, 145-168.

MÉSZÁROS, O., SERLEGI, G. 2011: The Impact of Environmental Change on Medieval Settlement Structure in Transdanubia, Acta Archaeologica Academiae Scientiarum Hungaricae 62, 199-219.

NÉMETHY, L. 1884: Adatok Árpádházi Boldog Margit ereklyéinek történetéhez. Rudnyánszky Ny., Budapest.

PÁLÓCZI HORVÁTH, A. 1979: Nagymaros rétegviszonyainak kutatása. In: Kemenczei, T. (Ed.): Dunai Régészeti Hirradó 1. Régészeti feltárások a dunai vizlépcsőrendszer területén 1978-ban. Magyar Nemzeti Múzeum, Budapest, 47-51.

PÉTERFI, B. 2011: Újabb adalékok Árpád-házi Margit középkori csodáinak sorához. In: Kádár, Z., Mkó, G., Péterfi, B., Vadas, A. (Eds.): Micae mediaevales. Tanulmányok a középkori Magyarországról és Európáról. ELTE Történelemtudományok Doktori Iskola, Budapest, 83-105.

PFISTER, C. 1999: Wetternachhersage. 500 Jahre Klimavariationen und Naturkatastrophen (1496-1995). Paul Haupt, Bern.

PIŠÚT, P., TIMÁR, G. 2009: A csallóközi Duna-szakasz folyódinamikai változásai a középkortól napjainkig. In: Kázmér, M. (Ed.): Környezettörténet. Az elmúlt 500 év környezeti eseményei történeti és természettudományi források tükrében. Hantken Kiadó, Budapest, 55-70.

ROHR, C. 2005: The Danube Floods and their Human Response and Perception (14 th to $\left.17^{\text {th }} \mathrm{C}\right)$, History of Meteorology 2, 71-86.

ROHR, Ch. 2007: Extreme Naturereignisse im Ostalpenraum. 
Naturerfahrung im Spätmittelalter und am Beginn der Neuzeit. Böhlau, Köln.

SÁGI, K. 1968: A Balaton vízállástendenciái 1863-ig a történeti és kartográfiai adatok tükrében. A Veszprém megyei múzeumok közleményei 7, 441-468.

SÁGI, K. 1970: Egy történeti vita természettudományos vonatkozásai, Földrajzi Értesitő 19, 200-207.

SÁGI, K., FÜZES, M. 1973: Újabb adatok a Balaton 1863 előtti vízállástendenciáinak kérdéséhez, Somogyi Múzeumok Közleményei 1, 247-261. SÜMEGI, P., JAKAB, G., MAJKUT, P., TÖRÖCSIK, T., ZATYKÓ, C. 2009b: Middle Age paleoecological and paleoclimatological reconstruction in the Carpathian Basin, Idojjárás 113/4, 265-298.

SÜMEGI, P., JAKAB, G., PERSAITS, G., TÖRÖCSIK, T., CSÖKMEI, B., NÁFRÁDI, K. 2006: A kaszói Baláta-tó középkor végi és újkori fejlödéstörténete történeti ökológiai, környezettörténeti vizsgálatok alapján. In: Kázmér, M. (Ed.): Környezettörténet 2006 Konferencia elöadásainak összefoglalói. Hantken Kiadó, Budapest, 46-47.

SÜMEGI, P., TÖRŐCSIK, T., JAKAB, G., GULYÁS, S., POMÁZI, P., MAJKUT, P., PÁLL1, D. G., PERSAITS, G., BODOR, E. 2009a: The environmental history of Fenékpuszta with a special attention to the climate and preciptation of the last 2000 years, Journal of Environmental Geography 2/3-4, 5-14.

SZÉKELY, B., MOLNÁR, G., TIMÁR, G. 2009: Lázár deák és a folyódinamika - térképezési hibák vagy valós mederváltozás?. In: Kázmér, M. (Ed.): Környezettörténet. Az elmúlt 500 év környezeti eseményei történeti és természettudományi források tükrében. Hantken Kiadó, Budapest, 71-94.

SZENDE, K. 2010: Stadt und Naturlandschaft im ungarischen Donauraum des Mittelalters. In: Oppl, F., Sonnlechner, C. (Eds.): Europäische Städte im Mittelalter. Studien Verlag, Innsbruck, 365-400.
TORMA, I. 1979: Magyarország régészeti topográfiája. Komárom megye régészeti topográfiája. Esztergom és a dorogi járás. MTA, Budapest.

TORMA, I. 1986: Magyarország régészeti topográfiája. Pest megye régészeti topográfiája. A budai és szentendrei járás. MTA, Budapest.

TORMA, I. 1993: Magyarország régészeti topográfiája. Pest megye régészeti topográfiája. A szobi és a váci járás. MTA, Budapest.

VADAS, A. 2011: Late Medieval Environmental Changes of the Southern Great Hungarian Plain - A Case Study, Annual of the Medieval Studies at CEU 17, 41-60.

VADAS, A. 2011: Az 1310-es évtized környezeti krízisének megjelenése Kelet-Közép-Európában és a Kárpát-medencében. In: Kázmér, M. (Ed.): Környezettörténet 2. Környezeti események a honfoglalástól napjainkig történeti és természettudományi források tükrében. Hantken Kiadó, Budapest, 57-77.

VÉGH, A. 2004: Matrakcsi Nászuh Buda ábrázolása, Budapest Régiségei $38,207-215$.

ZATYKÓ, C. 2008: The Medieval Environment of the Lake Baláta in the Light of Geology and Documentary Sources. In: Szabó P., Hédl, R. (Eds.): Human Nature. Studies in Historical Ecology \& Environmental History. Institute of Botany of the ASCR, Brno, 124-129.

ZATYKÓ, C., JUHÁSZ, I., SÜMEGI, P. 2007: Environmental Archaeology in Transdanubia. Magyar Tudományos Akadémia Régészeti Intézete, Budapest.

ZSIDI, P. 2008: A Duna szerepe Aquincum topográfiájában, Budapest Régiségei 41, 57-83. 